\title{
Antalya, Isparta ve Afyonkarahisar İllerinde Bulunan Su Ürünleri İşleme Tesislerinin Güncel Durumu
}

\author{
Hüseyin ERKEÇ*1무, Şengül BİLGíN² \\ ${ }^{1}$ T.C. Tarım ve Orman Bakanlığı, İzmir İl Tarım ve Orman Müdürlüğü, Balıkçılık ve Su Ürünleri Şube \\ Müdürlüğü, İzmir, Türkiye \\ ${ }^{2}$ Isparta Uygulamalı Bilimler Üniversitesi, Eğirdir Su Ürünleri Fakültesi, Isparta, Türkiye \\ * Sorumlu Yazar: erkoc3242@gmail.com
}

Araştırma Makalesi

Geliş 28 Haziran 2019; Kabul 30 Aralık 2019; Basım 01 Mart 2020.

Alıntılama: Erkeç, H., \& Bilgin, Ş. (2020). Antalya, Isparta ve Afyonkarahisar illerinde bulunan su ürünleri işleme tesislerinin güncel durumu. Acta Aquatica Turcica, 16(1), 51-65. https://doi.org/10.22392/actaquatr.584098

\section{Özet}

Bu çalışmada Göller Bölgesi'nin su ürünleri üretiminde lider konumda olan Antalya, Isparta ve Afyonkarahisar'da faaliyet gösteren toplam 13 su ürünleri işleme tesisi incelenmiştir. Çalışma için önceden belirlenen soruların bulunduğu anket formu hazırlanmıştır. Ankette işletmelerin kuruluş tarihleri, kuruluş yerleri, kurulu kapasiteleri, personel durumu, hijyen durumu, iş güvenliği durumu, uluslararası almış oldukları kalite belgeleri, hammadde temin şekilleri, işleme yöntemleri, üretim ve ihracat durumu ve işleme tesislerinin karşılaşmış oldukları problemler ile ilgili bilgilere yer verilmiştir.

Anket sonuçlarına göre genel olarak işleme tesislerinin Isparta ve Afyonkarahisar'da eşit şekilde dağılım gösterdiği belirlenmiştir. Antalya'da 5, Isparta ve Afyonkarahisar'da 4'er tesis yerinde ziyaret edilerek anket formları doldurulmuştur. Tesislerde bayan işçiler daha çok olmak üzere daimi işçiler çalışmaktadır. Sorumlu yöneticilerin çoğunu su ürünleri mühendisleri oluşturmaktadır. Tesislerin tümünde HACCP uygulanmakta olup hijyen eğitimini almış, iş güvenliği eğitiminden geçmiş personel çalışmaktadır. Tesislerde iş güvenliği şirketleriyle anlaşmalı iş güvenliği uzmanı bulunmaktadır. Hammadde temininin hem yerli hem de yabancı üreticilerden karşılandığı tespit edilmiştir. Genellikle tüm tesislerin ihracat yaptığı tespit edilmiştir. En çok karşılaşılan problemler kalifiye elaman bulmaktaki güçlükler ve hammadde sıkıntısı olarak tespit edilmiştir.

Anahtar kelimeler: Su ürünleri, işleme tesisi, kalite, Göller Bölgesi, Türkiye

Current situation of seafood processing plants in Antalya, Isparta and Afyonkarahisar provinces.

\section{Abstract}

In this study, a total of 13 seafood processing plants located in Antalya, Isparta and Afyonkarahisar, which are the leader in the seafood production of the Lakes Region, were investigated. A survey form was prepared for the study. The survey includes information on the establishment dates, establishment locations, installed capacities, personnel status, hygiene status, occupational safety status, international quality certificates, raw material procurement methods, processing methods, production and export status, and problems encountered by processing plants.

According to the results of the survey, it was determined that the seafood processing plants were distributed evenly in Antalya, Isparta and Afyaonkarahisar. 5 processing plant in Antalya, 4 processing plant in Isparta and 4 in Afyonkarahisar were visited at the site and the survey were filled. At the facilities, women work mainly and the permanent workers are working intensively. Most of the responsible managers are aquaculture engineers. In all of the facilities, HACCP is applied and there is personnel who have received hygiene training and who have been trained in occupational safety. Facilities include a contracted occupational safety specialist with occupational safety companies. It is determined that raw material is obtained from both domestic and foreign producers. Generally all facilities are exporting. The most common problems were identified as difficulties in finding qualified personnel and a shortage of raw materials.

Keywords: Seafood, processing plant, quality, Lake District, Turkey

\section{GIIRIŞ}

Yapılan araştırmalara göre su ürünleri sektörü dünyada en hızlı büyüyen sektördür. Bitkisel ve hayvansal üretim, ormancılıkla birlikte tarımın dört alt sektöründen birisidir (Kömürlü ve Atar, 2019). Ülkemizi çevreleyen denizler, çok sayıda doğal göl ve yapay gölete sahip olmamız, bu kaynakların 
balık yetiştiriciliğine uygun olması su ürünleri potansiyeli için önem arz etmektedir. Türkiye son zamanlarda su ürünleri sektörü olarak üretim ve ekonomi açısından önemli yol kat etmiş olsa da istenilen düzeyde değildir.

Hayvansal protein gereksinimini karşılamak için daha ucuz ve proteince daha zengin olan su ürünleri, dünya besin gereksiniminin önemli kısmını karşılayan temel bir endüstridir. Özellikle son 50 yılda eğitimler ve teknoloji sayesinde şaşırtıcı bir gelişim göstermiş, FAO tarafından dünyada en hızlı büyüyen gıda sektörü olarak belirlenmiştir (Dağtekin ve Ak, 2007).

$\mathrm{Su}$ ürünleri sağlıklı beslenme önerilerinin vazgeçilmezleri arasında yer alan bir besin maddesi olmasına rağmen; ülkemizde kişi başına su ürünleri tüketimimiz $\mathrm{AB}$ ülkeleri ve dünyadaki diğer gelişmiş ülkelerin balık tüketim ortalaması altında kalmaktadır. Su ürünlerinin cazip hale getirilmesi ve farklı damak tatlarının oluşturulmasında en önemli sektör su ürünleri işleme sektörüdür. Gelişen gıda teknolojileri ile birlikte farklı su ürünleri işleme teknolojilerinin ülkemizde uygulanması ülke ekonomisine katkı sağlamakla birlikte su ürünlerini ülkemizde cazip bir gida maddesi haline getirebileceği düşünülmektedir.

Türkiye su ürünleri üretimi bakımından dünyada 35., Avrupa ülkeleri arasında ise İngiltere'den sonra 6'ncı sıradadır. Türkiye'de 2017 yılı üretiminin \%51,1'i avcıllk yoluyla denizden, \%5,' i iç sulardan ve \%43,9'u da yetiştiricilikten elde edilmiştir (www.tuik.gov.tr). Türkiye'de 2017 yılı TÜİK verilerine göre 630.820 ton su ürünleri üretimi gerçekleşmiştir. Bu üretimin yaklaşık 354 bin tonu avc1lı yoluyla 276 bin tonu ise yetiştiricilik yoluyla elde edilmiştir. Bu ürünlerin 156 bin tonu ise başka ülkelere hammadde, işlenmiş ve yarı işlenmiş olarak ihraç edilmektedir (www.tuik.gov.tr).

Ülkemizdeki işletmelerin büyük bir kısmı AB başta olmak üzere dış ülkelere ihracat yapmaktadır. Bir kısmı ise üçüncü dünya ülkeleri ve iç piyasaya ürün vermektedir. Özellikle AB' ne ihracat yapmak üzere onaylanmış işletmeler $\mathrm{AB}$ uzmanları tarafından da denetime tabi tutulmaktadır (Anonim, 2014). Göller Bölgesi'nde yer alan Antalya-Isparta-Afyonkarahisar illerinde bulunan 13 adet su ürünleri işleme tesisleri tüm Türkiye'de bulunan su ürünleri işleme tesislerinin \% 5'ini oluşturmaktadır.

2019 yılı itibariyle ülkemizde, Gıda Tarım ve Hayvancılık Bakanlığı'na kayıtlı 248 adet balık, çift kabuklu yumuşakça, kurbağa bacağı ve salyangoz işleyen tesis bulunmaktadır. Bunların tamamı aktiftir. Bu işletmelerin iller bazında dağılımına bakıldığında İzmir, İstanbul, Muğla ve Trabzon illerinin önde geldiği görülmektedir (www.tarimorman.gov.tr). Bu işletmelerden İzmir, Muğla, Trabzon, Denizli, Kayseri, Elazı̆̆ Kahramanmaraş, Malatya gibi illerde bulunan tesislerde genellikle kültür balıkları işlenmektedir. Bu tesislerde balıkların büyük bir kısmı, taze-soğutulmuş olarak değerlendirildiği gibi; dondurulmuş, fileto ve füme olarak da işlenmektedir. Deniz kültür balıkları içerisinde levrek ve çipura daha çok taze- soğutulmuş, dondurulmuş ve fileto olarak işlenirken, alabalık bu formların yanı sıra füme olarak da işlenmektedir.

2014 y1lı su ürünleri işleme tesislerinin toplam kapasiteleri 100 bin ton/yıla yakındır. Ancak bu kapasitenin diğer gıda ürünlerinde olduğu gibi \% 65'i kullanılmaktadır (Anonim, 2014). Çalışmanın yapıldığı dönemde ülkemiz genelindeki su ürünleri işleme tesis sayısı 216 olup bunlardan 13 adet işleme tesisi Antalya (5) Isparta (4) ve Afyonkarahisar' da (4) bulunmakta idi (www.ggbs.tarim.gov.tr). 2019 yılı itibarıyla Antalya'daki su ürünleri işleme tesis sayısı artarak 8'e yükselmiştir (www.ggbs.tarim.gov.tr). Yapılan çalışmada bahsi geçen illerde bulunan işleme tesislerinin kurulu kapasitesi, personel durumu, işleme yöntemleri, işlenen türler, pazar durumu, ham madde temin yöntemi, yıllık üretim miktarları ve ihracat miktarları hakkında bilgiler edinilmiş olup ülke ve bölge ekonomisi için önemi ortaya konulmaya çalışılmıştır.

\section{MATERYAL ve YÖNTEM}

Çalışmada Afyonkarahisar, Antalya ve Isparta'da kurulmuş olan toplam 13 su ürünleri işleme tesisi ziyaret edilmiştir. Çalışma yapılacak illerdeki aktif durumda olan su ürünleri işleme tesisleri Tarım ve Orman Bakanlığı'na ait Gıda Güvenliği Bilgi Sistemi üzerinden tespit edilmiştir. Tesisler yerinde ziyaret edilmiş; bölgede bulunan İl Tarım ve Orman Müdürlüklerinden yardım alınmıştır.

Birebir görüşmelerde tesislerin sorumlu yöneticisi veya sorumlu müdürü, firma yöneticilerine çalışmamızla ilgili sorular yöneltilmiş̧tir. Çalışmamızda işletme gizliliğine titizlikle önem verileceği bildirilmiş ve çalışmanın hedefine ulaşması için bilgilerin doğruluğunun önemine değinilmiştir. İşletme yetkilileri ile birlikte işleme tesisleri gezilmiştir. Hammadde girişinden mamul madde çıkış sürecine kadar, çalışanların ve işleme tesisinin hijyen uygulamaları incelenmiştir. 
İşletmelere aşağıda verilen anket bilgi formundaki sorular yöneltilmiştir. Anketin hazırlanmasında kendi hazırladığımız soruların yanı sıra Aral (2009) ve Ünlüsayın vd. (2005)'ten de yararlanılmıştır. $\mathrm{Bu}$ sorularla işletmenin kurulu kapasitesi, yerleşim yerine uzaklığı, kuruluş yılı üretim ve ihracat miktarları, uluslararası kalite belgeleri, iş güvenliği durumu, işleme yöntemleri, personel durumu ile ilgili bilgiler hedeflenmiştir. Tesisler numaralandırılarak anketler hazırlanmıştır. Sadece faaliyet gösterdikleri ve bağlı bulundukları il belirtilmiştir.

\section{SU ÜRÜNLERİ İSLEME TESISİ ANKET BILLGI FORMU}

1) İşletmenin adı, kuruluş yeri ve y1lı?

2) İşletmenin kurulu kapasitesi nedir?

3) İşletmede bulunan personel durumu ve sayısı?

a- Sezonluk işçi

b- Daimi işçi

c- Yevmiyeci işçi

d- Tekniker

e- Su Ürünleri Mühendisi

f- Gida Mühendisi

g- Ziraat Mühendisi

h- Veteriner Hekim

1- Biyolog

i- Diğer

4) İşletmede çalışan personel hijyen eğitimi aldı mı?

a- Evet

b- Hayır

5) İşletmede çalışanların yaş aralıkları nedir?

a. $18-25$

b. $25-30$

c. $30-35$

d. $35-45$

e. 45 ve üzeri

6) İşletmede çalışanların cinsiyet dağ 1 lımı?

f. Erkek

g. Kadin

7) İşletmede çalışanların kaçı balık tüketiyor?

8) İşletmede çalışanların eğitim durumu?

a. İlkokul

b. Ortaokul

c. Lise

d. Önlisans

e. Lisans

f. Yüksek lisans / Doktora

9) İşletmede bulunan personel iş güvenliği eğitimi aldı mı?

a. Evet

b. Hayır

10) İşletmeye ait iş güvenliği uzmanı bulunuyor mu?

a. Evet

b. Hayır

11) İşletmede bulunan ulusal ve uluslararası kalite belgeleri nelerdir?

12) İşletmede HACCP uygulanıyor mu?

a. Evet

b. Hayır

13) İşletmeye gelen hammaddenin ediniliş şekli nedir?

a. Avc1lik

b. Yetiştiricilik 
14) İşletmeye gelen hammadde kaynağı?

a. Yerli

b. Yabanc1

15) İşletmede işlenen türler nelerdir?

a. Balık (Balık Türleri)

b. Çift Kabuklu Yumuşakçalar (Çift kabuklu yumuşakça türleri)

c. Diğer

16) İşletme ürünlerini nasıl değerlendirmektedir?

a. İç piyasada değerlendirilmektedir.

b. Avrupa birliği ülkelerine ihraç edilmektedir.

c. $\mathrm{AB}$ dişında bulunan ülkelere ihraç edilmektedir.

17) İşletme tam kapasite çalışıyor mu? Yüzde kaç oranla çalışıyor?

a. Evet

b. Hayır

Oran \% ( )

18) İşleme tesisinde kullanılan işleme yöntemleri nelerdir?

a. Taze /Soğutulmuş ve Dondurulmuş (Vide, Fileto) ürün

b. Tuzlanmış ve Marine ürün

c. Dumanlanmış ürün

d. Konserve ürün

e. Diğer

19) İşletmenin yerleşim yerine olan uzaklığı ne kadardır?

a. $0-5 \mathrm{~km}$

b. $\quad 5-10 \mathrm{~km}$

c. $\quad 10-50 \mathrm{~km}$

d. $\quad 50 \mathrm{~km}$ ve üzeri

20) İşletmenin yı1lık üretim miktarı ne kadardır?

a. $\quad 0-500$ ton/yil

b. $500-1000$ ton $/ \mathrm{y} 1$

c. $1000-5000$ ton $/ \mathrm{y} 1$

d. 5000 ton/ y1l ve üzeri

21) İşletme son yıllarda ortalama ihracat miktarı ne kadardır?

a. $0-500$ ton/yil

b. $500-1000$ ton $/ \mathrm{y} 11$

c. $1000-5000$ ton $/ \mathrm{y} 1$

d. 5000 ton ve üzeri/y1

22) İşletmenin en çok karşılaşmış olduğu problemler nelerdir?

\section{BULGULAR ve TARTIŞMA}

İşletmelerin Kuruluş Tarihleri

$\mathrm{Su}$ ürünleri işleme sektörü son yıllarda hızla gelişmektedir. Bu işletmelerin çoğunun bölgede bulunan yetiştiricilik ve avcılık ürünlerinin değerlendirilmesi üzerine kurulduğu anlaşılmaktadır. Yıllar geçtikçe sektörün daha da profesyonel olarak üretim yaptığı, tesislerde gerekli teknik ve hijyenik şartların tam olarak uygulandığ gözlenmiştir. Tesisler ihracat yapmak için kendilerini yenileyip geliştirmek zorunda kalmışlar ve HACCP uygulamasına geçmişlerdir. 


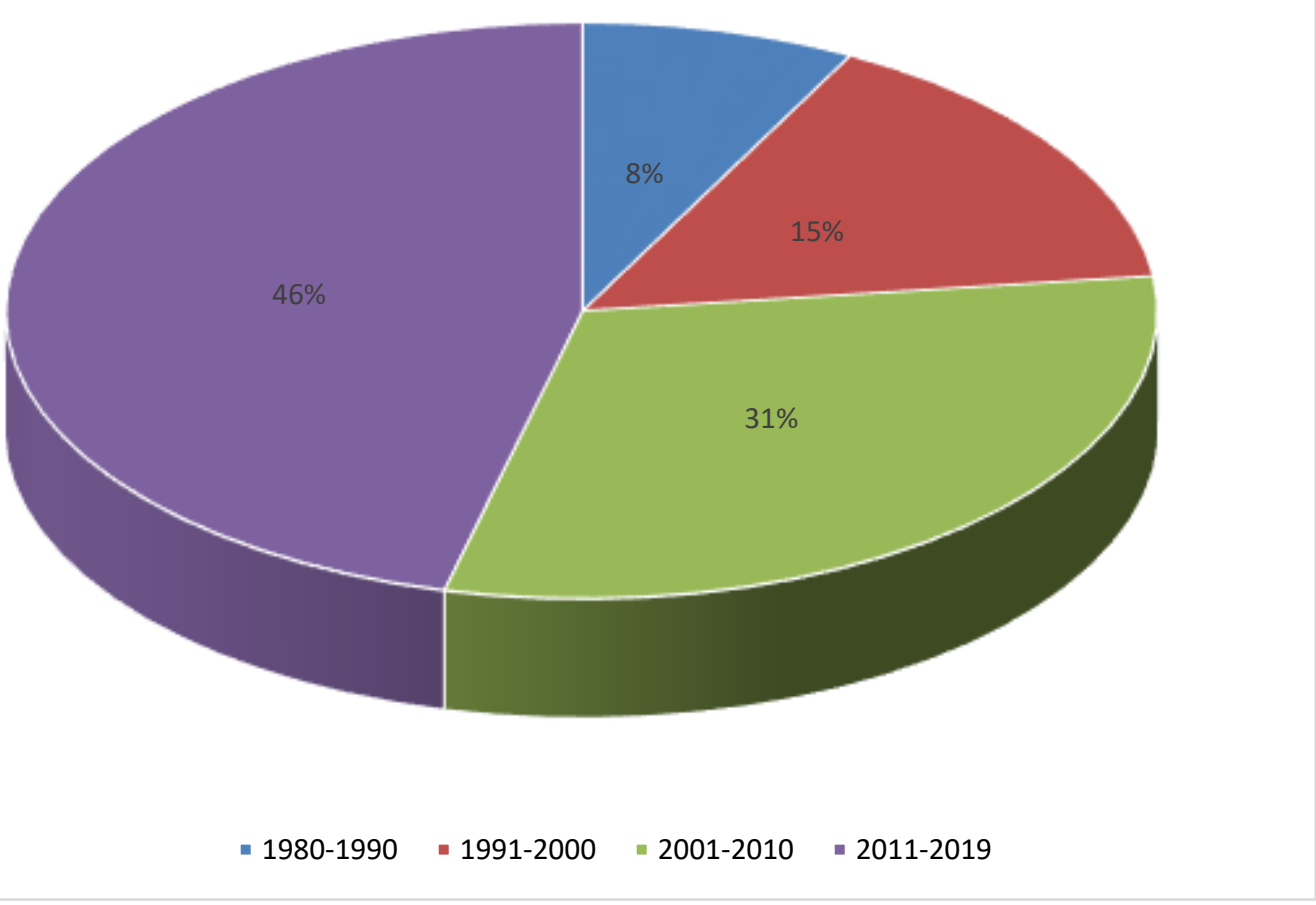

Şekil 1. Çalışmadaki işletmelerin kuruluş tarihlerine göre dağılımı

\section{İşletmelerin İllere Göre Dağılımı}

İncelenen tesislerin kuruluş yerlerine bakılınca avcılık ve yetiştiriciliğin yoğun olarak yapıldığ iller olduğu tespit edilmiştir. Çalışılan tesislerin birbirine yakın olduğu tespit edilmiş olup daha çok deniz ürünlerinin değerlendirildiği Antalya'da 5 adet, Isparta'da 4 adet, Afyonkarahisar'da 4 adet su ürünleri işleme tesisi bulunduğu belirlenmiştir (Şekil 2).

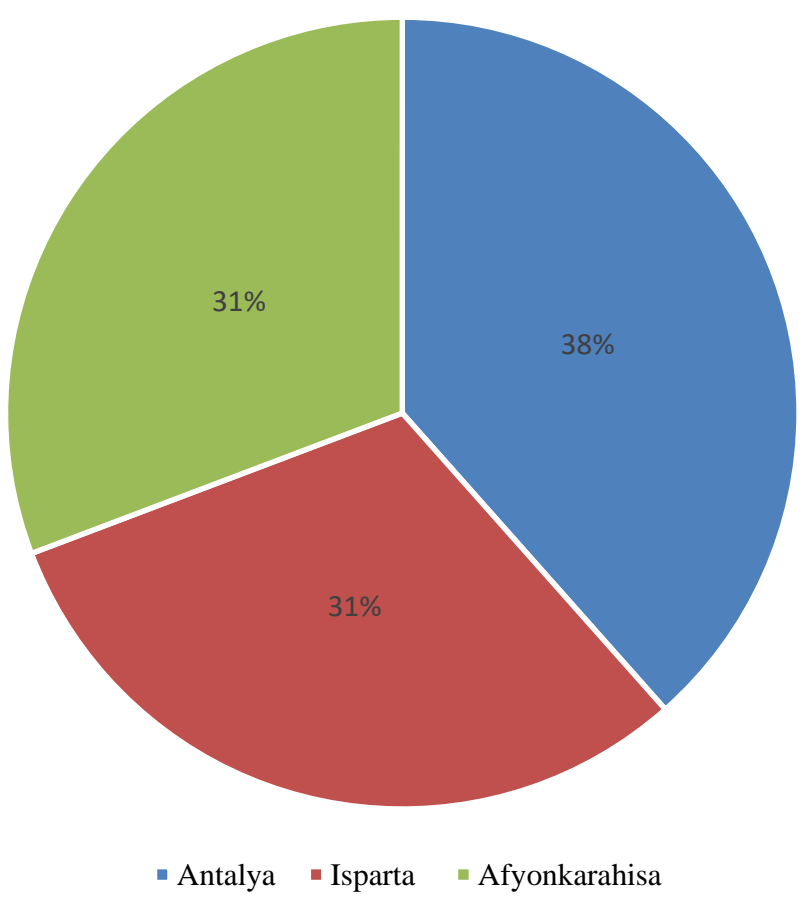

Şekil 2. İncelenen tesislerin illere göre dağılımı 


\section{İşletmelerin Kurulu Kapasiteleri}

İşleme tesislerinin hammadde temini, bölgedeki konumu tesislerin kurulu kapasitesini etkilemektedir. Antalya İli'nde bulunan işleme tesislerinin hem tatlı su hem deniz ürünlerini işlemesi ve bu ürünlerin temininin kolaylığı nedeniyle kurulu kapasiteleri 19408 ton/yıl iken, Isparta İli için 3522 ton/yıl, Afyonkarahisar İli için 3030 ton/yıldır (Şekil 3).

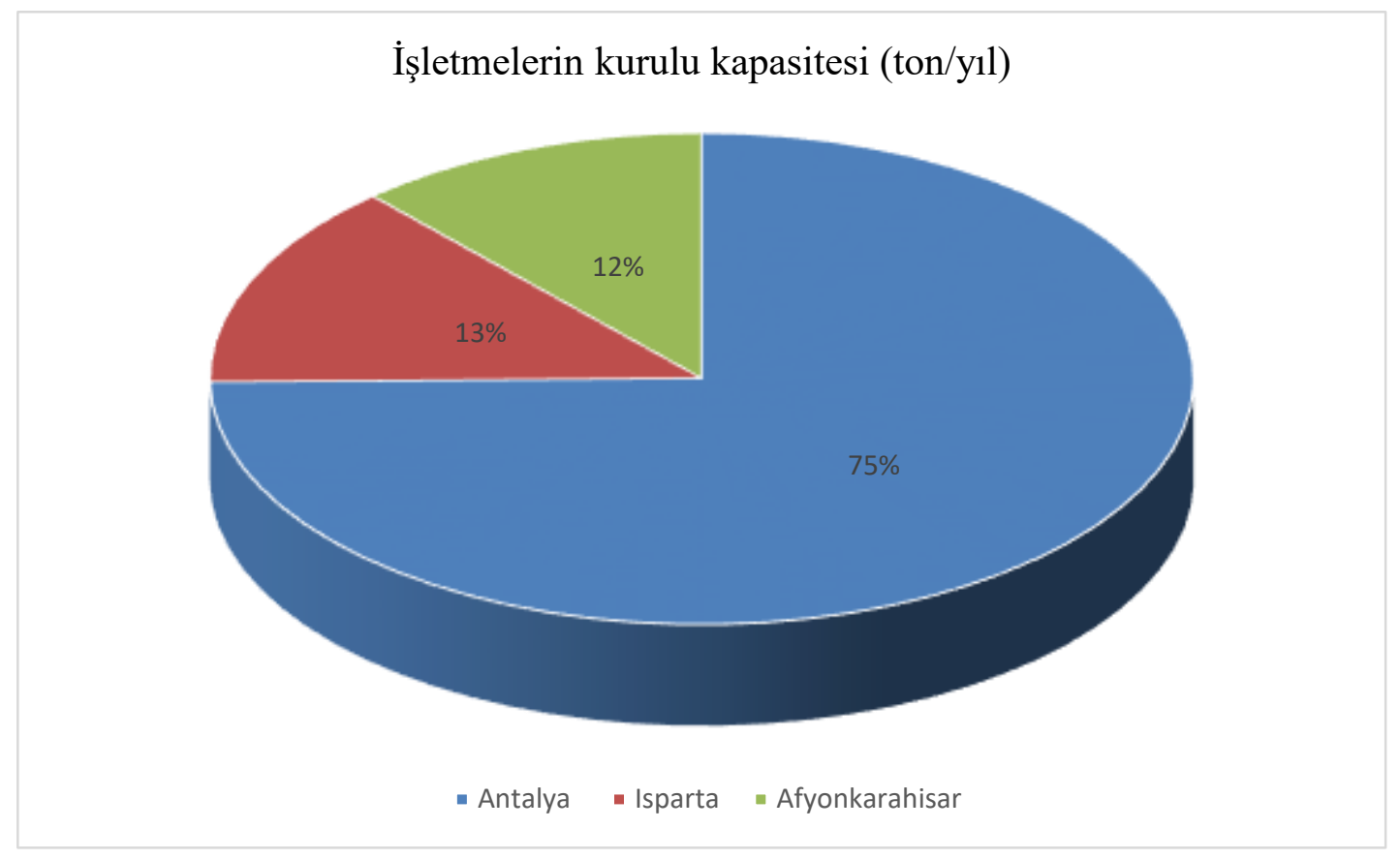

Şekil 3. İncelenen tesislerin illere göre kurulu kapasite dağılımı

\section{Çalışmadaki İşleme Tesislerinde Personel Dağılımı}

Yapılan çalışmada personel durumu ile ilgili elde edilen verilere göre; avcılık sezonuna bağlı olarak çalışan sayısı değişebilmektedir. Afyonkarahisar'da bulunan sadece kerevit işleyen bir tesis daha çok sezonluk iş̧̧i çalıştırmaktadır. Antalya'da bulunan başka bir tesis hem avcılık hem yetiştiricilik ürünlerini işlediği için daimi işçiyi daha fazla çalıştırmaktadır. Araştırmamıza konu olan işletmelerde; 117 sezonluk işçi, 281 daimi işçi 23 yevmiyeci işçi, 10 tekniker, 22 su ürünleri mühendisi, 1 gıda mühendisi ve 12 diğer (aşçı, şoför, güvenlikçi vb) personel çalışmaktadır. Sorumlu müdürler genellikle su ürünleri mühendislerinden seçilmektedir. Bu işler genellikle işleme tesislerinde vide, fileto çıkarma, taze soğutulmuş ve dondurulmuş ürünlerin hazırlanmasında, kerevit ve salyangoz temizlemede, paketleme ve ürün kabulünde, tütsülemede görev almaktadır. Ayrıca işleme tesisinin hijyeninden sorumlu kişiler de bulunmaktadır. Elde edilen veriler doğrultusunda tesislerin personel dağılımı Şekil 4'te gösterilmiştir. 


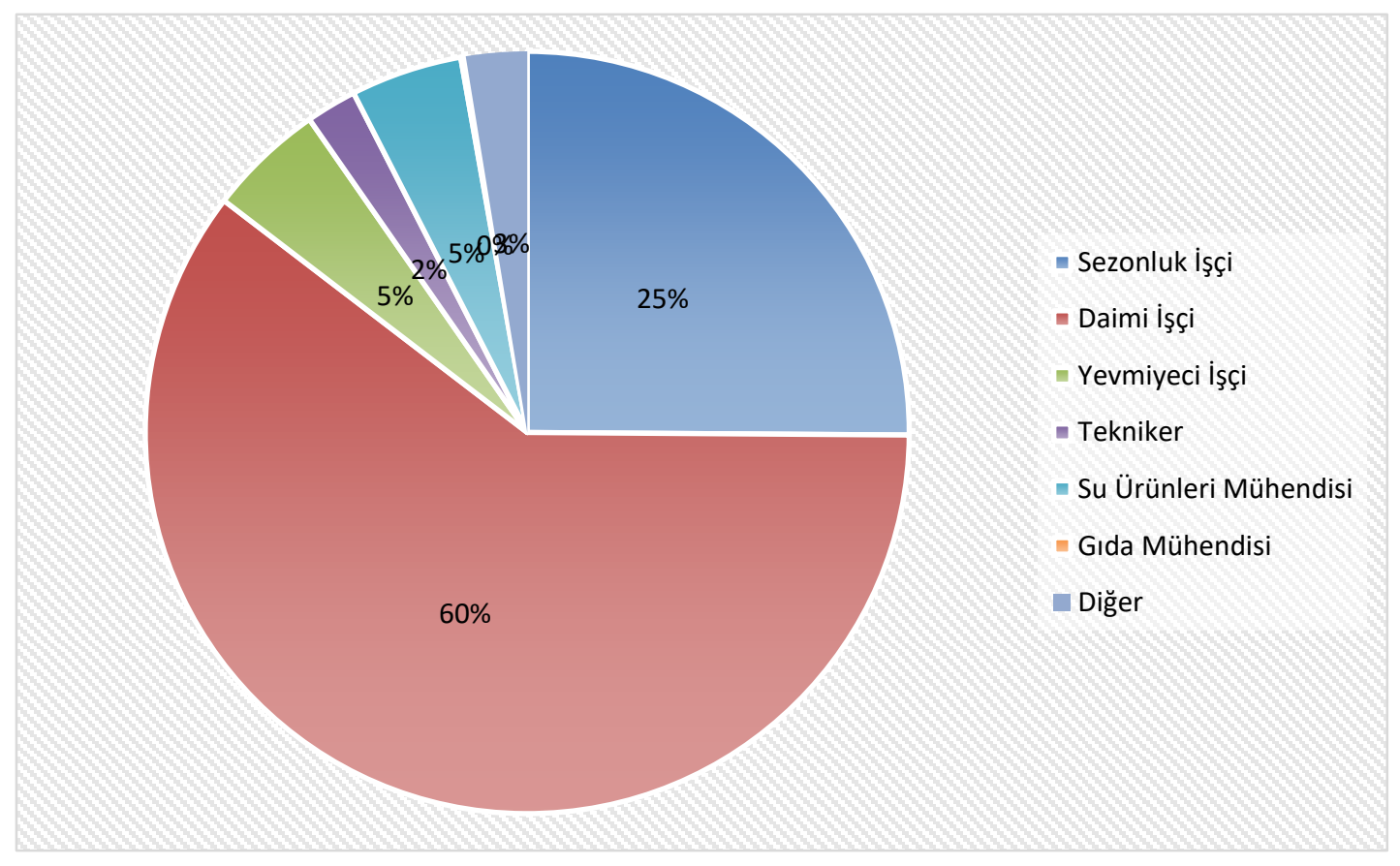

Şekil 4. Incelenen işleme tesislerinin personel dağılımı

\section{Tesislerde Çalışan Personelin Yaş Gruplarına Göre Dağılımı}

Yapmış olduğumuz çalışmada 18-25 yaş gurubundan 54 kişi, 25-30 yaş gurubundan 144 kişi, 3035 yaş gurubundan 131 kişi, 35-45 yaş gurubundan 92 kişi, 45 yaş üstü yaş gurubundan 25 kişi çalıştığ 1 belirlenmiştir. Tespit edildiği üzere orta yaş grubu işleme tesislerinde daha çalışmaktadır. Yaş gruplarına göre personel dağglımı Şekil 5'te gösterilmiştir.

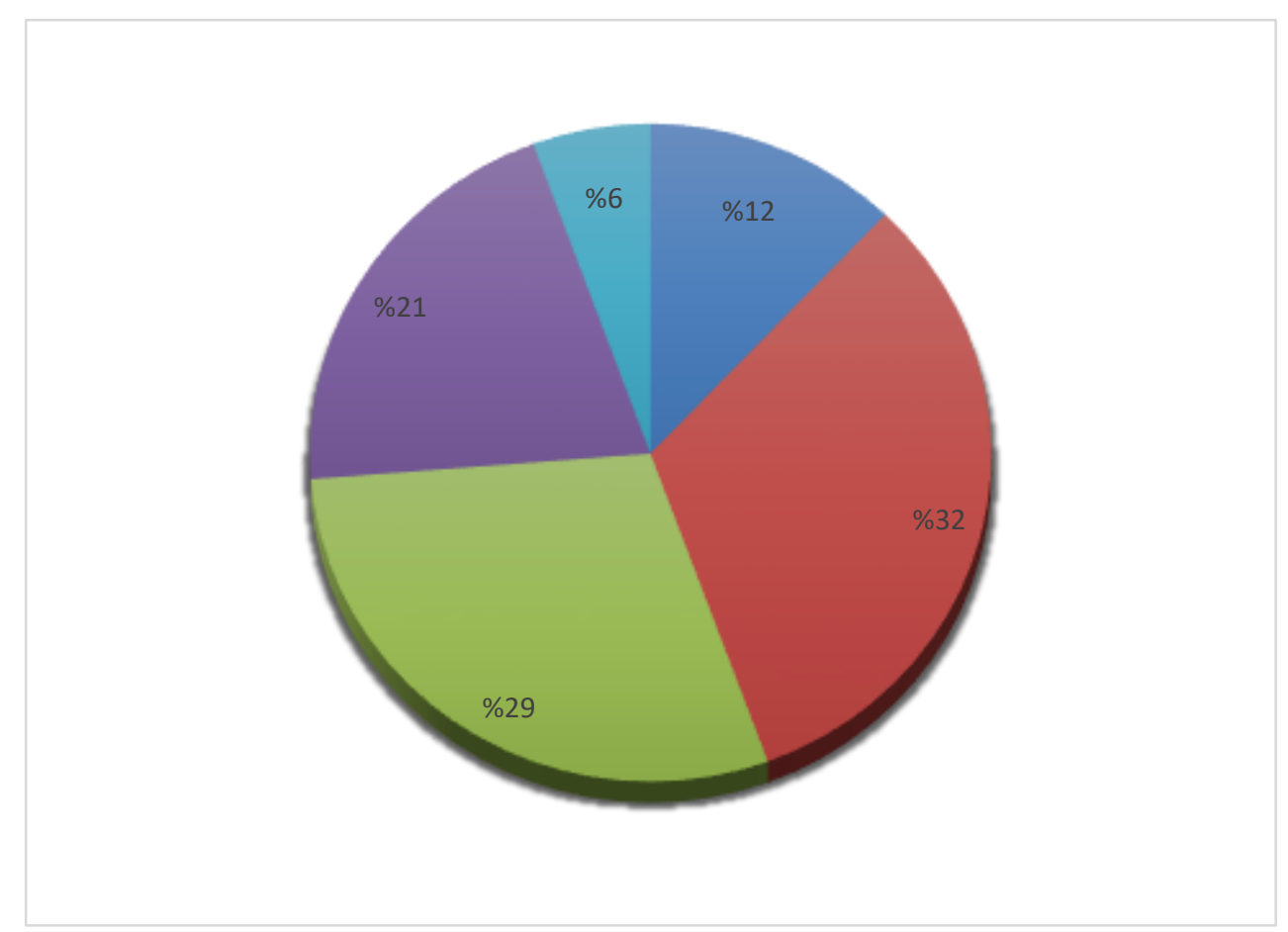

Şekil 5. İncelenen tesislerinde çalışan personelin yaş guruplarına göre dağılımı 


\section{İncelenen Tesislerde Cinsiyet Dağılımı}

Su ürünleri işleme tesislerinde çalışan personelden çoğunun kadın olduğu, işleme tesislerinin büyük bölümünün kadın personel tercih ettiği tespit edilmiştir. İncelenen tesislerde çalışanların 305'ini kadın, 141'ini erkek personel oluşturmaktadır (Şekil 6).

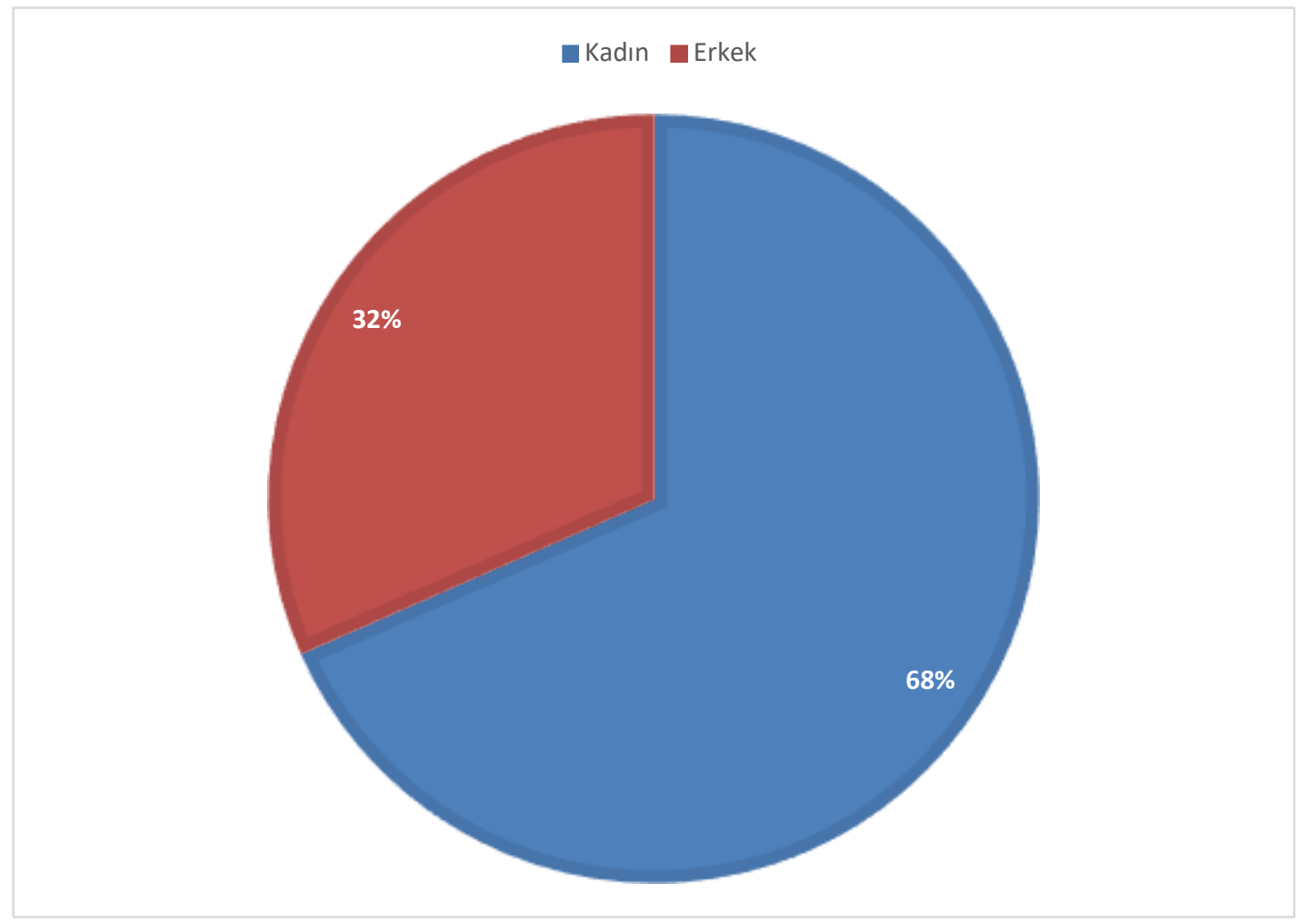

Şekil 6. İncelenen tesislerdeki çalışan personelin cinsiyet dağılımı

Araştırmanın yapıldığı tesislerde çalışan personele balık tüketimi hakkında sorular sorulmuştur. Tüm tesislerdeki çalışanlar balık tükettiğini beyan etmişlerdir. Çalışanların birçoğunun ilköğretim mezunu olduğu tespit edilmiştir. Çalışanların genellikle tesisin bulunduğu yörenin insanlarından seçilmiş olduğu, sorumlu yöneticiler ve bazı teknikerlerin tecrübesine önem verildiği gözlenmiştir. En çok ihtiyaçlardan birisi de tecrübeli kalifiye eleman bulma sorunu olduğu görülmüştür. Söz konusu tesislerde çalışanların hepsinin iş güvenliği ve hijyen eğitimi aldıkları tespit edilmiştir. Bazı işletmeler kendi bünyesinde iş güvenliği uzmanı bulundurmakta iken bazıları ise iş güvenliği şirketleri ile sözleşme esasına göre iş güvenliği uzmanı bulundurdukları tespit edilmiştir.

\section{İşletmelerde Bulunan Uluslararası Kalite Belgeleri}

Çalışmamızda incelenen tesislerde uluslararası kalite belgeleri olarak Global GAP, IFS, BRC, ISO 9001, ISO 14001, ISO 22000, OHSAS 18001 ve HACCP belgesine sahip oldukları anlaşılmıştır. İncelenen 13 tesisten hepsinde HACCP, 12' sinde IFS, 9'unda BRC, 6'sinda ISO 9001, 4' ünde ISO 22000, 3'ünde GLOBAL GAP, 2'sinde ISO 14001 ve 1'inde OHSAS 18001 uluslararası kalite belgeleri bulunmaktadir.

\section{İşletmelerin Hammadde Temin Şekilleri}

Ülkemiz genelinde olduğu gibi incelenen su ürünleri işleme tesislerinde en büyük problemlerinden birisi hammadde teminidir. Çalışmamızdaki tesislerin 9'u hammaddeyi hem avcılık hem de yetiştiricilik yoluyla elde etmektedir. Geriye kalan 4 tesis ise sadece yetiştiricilik yoluyla hammadde kaynağı sağlamaktadır. Bu tesislerden hammadde kaynağı olarak 7'si yerli ve yabancı ürünleri kullanırken, 6 tanesi sadece yerli ürünleri tercih etmektedir (Tablo 1). 
Isparta ve Afyonkarahisar'da bulunan tesislerde daha çok alabalık, sudak, gümüşi havuz balığı, çipura, levrek, salyangoz, kerevit işlenmektedir. Deniz ürünlerinin bol olduğu Antalya'da ise; çipura, levrek, granyöz, somon, uskumru, palamut, hamsi, tekir sübye, kalamar, ahtapot, karides, yılan balığı, deniz 1stakozu ve alabalık işlenmektedir.

Tablo 1. İncelenen işletmelerde hammadde ediniliş şekli ve kaynağı

\begin{tabular}{ccccc}
\hline \hline & \multicolumn{2}{c}{ Hammadde ediniliş şekli } & \multicolumn{2}{c}{ Hammadde kaynağı } \\
Tesis No & Avcılık & Yetiştiricilik & Yerli & Yabancı \\
\hline 1 & $\mathrm{X}$ & $\mathrm{X}$ & $\mathrm{X}$ & $\mathrm{X}$ \\
2 & $\mathrm{X}$ & $\mathrm{X}$ & $\mathrm{X}$ & $\mathrm{X}$ \\
3 & & $\mathrm{X}$ & $\mathrm{X}$ & \\
4 & $\mathrm{X}$ & $\mathrm{X}$ & $\mathrm{X}$ & \\
5 & & $\mathrm{X}$ & $\mathrm{X}$ & \\
6 & $\mathrm{X}$ & $\mathrm{X}$ & $\mathrm{X}$ & \\
7 & & $\mathrm{X}$ & $\mathrm{X}$ & \\
8 & & $\mathrm{X}$ & $\mathrm{X}$ & \\
9 & $\mathrm{X}$ & $\mathrm{X}$ & $\mathrm{X}$ & $\mathrm{X}$ \\
10 & $\mathrm{X}$ & $\mathrm{X}$ & $\mathrm{X}$ & $\mathrm{X}$ \\
11 & $\mathrm{X}$ & $\mathrm{X}$ & $\mathrm{X}$ & $\mathrm{X}$ \\
12 & $\mathrm{X}$ & $\mathrm{X}$ & $\mathrm{X}$ & $\mathrm{X}$ \\
13 & $\mathrm{X}$ & $\mathrm{X}$ & $\mathrm{X}$ & $\mathrm{X}$ \\
\hline
\end{tabular}

\section{Kapasite Kullanım Oranlarına Göre İşletmelerin Dağılımı}

Çalışmadaki tesislerden 7 tanesi tam kapasite ile çalışırken, 6 tanesi \%50-90 arası kapasitede çalışmaktadır (Şekil 7). Bu tesislerden 3 tanesi ürünlerini iç piyasada, $A B$ ve $A B$ ülkeleri dişındaki ülkelere ihracat ile değerlendirmektedir. Diğer tesisler ya iç piyasada ya da $\mathrm{AB}$ ülkelerine ihracat yaparak değerlendirmektedir.

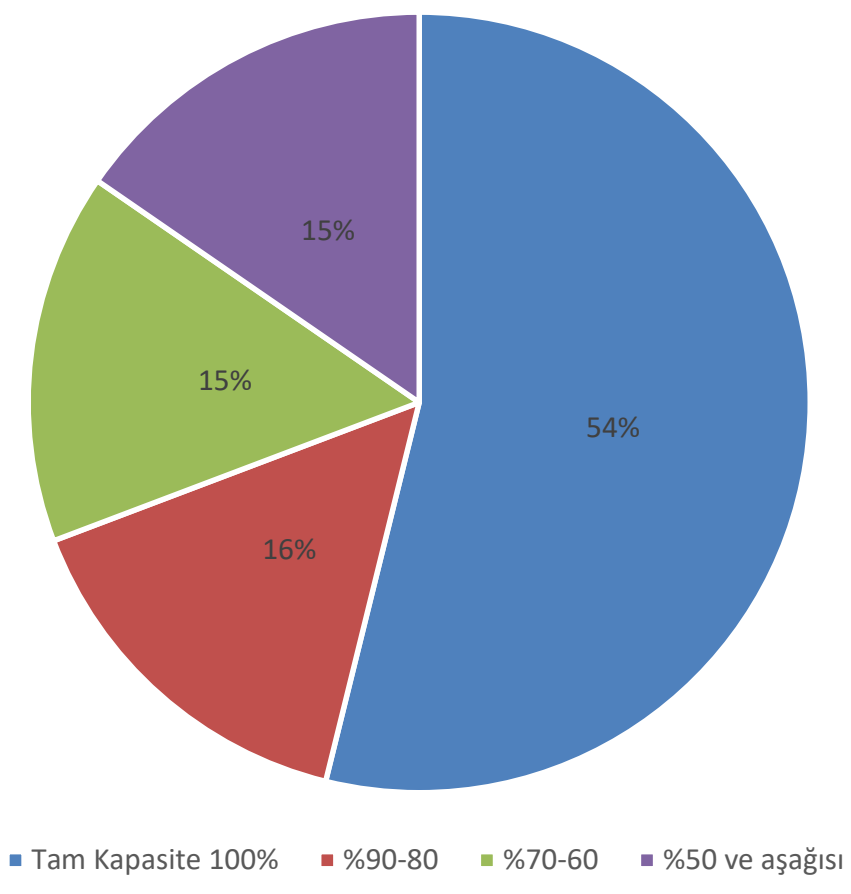

Şekil 7. Kapasite kullanım oranlarına göre tesislerin dağılımı 


\section{Tesislerin İşleme Yöntemleri}

İncelenen 13 tesisin ortak özelliği taze, soğutulmuş ya da dondurulmuş olarak ürünlerini işlemekte olup Afyonkarahisar'da bulunan bir tesis dumanlanmış ürünişlemektedir. Bazı tesisler ise özellikle Antalya'da bulunan tesisler konserve dişında tüm işleme yöntemlerini kullanmaktadır (Tablo 2).

Tablo 2. İncelenen tesislerdeki işleme yöntemleri

\begin{tabular}{ccccc}
\hline \hline Tesis No & $\begin{array}{c}\text { Taze/Soğutulmuş ve } \\
\text { Dondurulmuş Ürün } \\
\text { (Vide, Fileto) }\end{array}$ & $\begin{array}{c}\text { Tuzlanmış ve Marine } \\
\text { Ürün }\end{array}$ & $\begin{array}{c}\text { Dumanlanmiş } \\
\text { Ürün }\end{array}$ & $\begin{array}{c}\text { Konserve } \\
\text { Ürün }\end{array}$ \\
\hline 1 & $\mathrm{X}$ & & $\mathrm{X}$ \\
2 & $\mathrm{X}$ & & \\
3 & $\mathrm{X}$ & & \\
4 & $\mathrm{X}$ & & \\
5 & $\mathrm{X}$ & & $\mathrm{X}$ \\
6 & $\mathrm{X}$ & & $\mathrm{X}$ \\
7 & $\mathrm{X}$ & $\mathrm{X}$ & \\
8 & $\mathrm{X}$ & $\mathrm{X}$ & $\mathrm{X}$ \\
9 & $\mathrm{X}$ & & \\
10 & $\mathrm{X}$ & $\mathrm{X}$ & \\
11 & $\mathrm{X}$ & & \\
12 & $\mathrm{X}$ & & \\
13 & $\mathrm{X}$ & & \\
\hline \hline
\end{tabular}

\section{İşletmelerin Yerleşim Yerlerine Uzaklığı}

İncelenen tesislerin yerleşim yerine uzaklığındaki dağılım Şekil 8'de gösterilmiştir. Buna göre tesislerin \%23'ü yerleşim alanına 10-15 km uzaklıkta kurulmuşken \%38'i 5-10 km ve \%39'u 0-5 km uzaklıkta kurulmuştur.

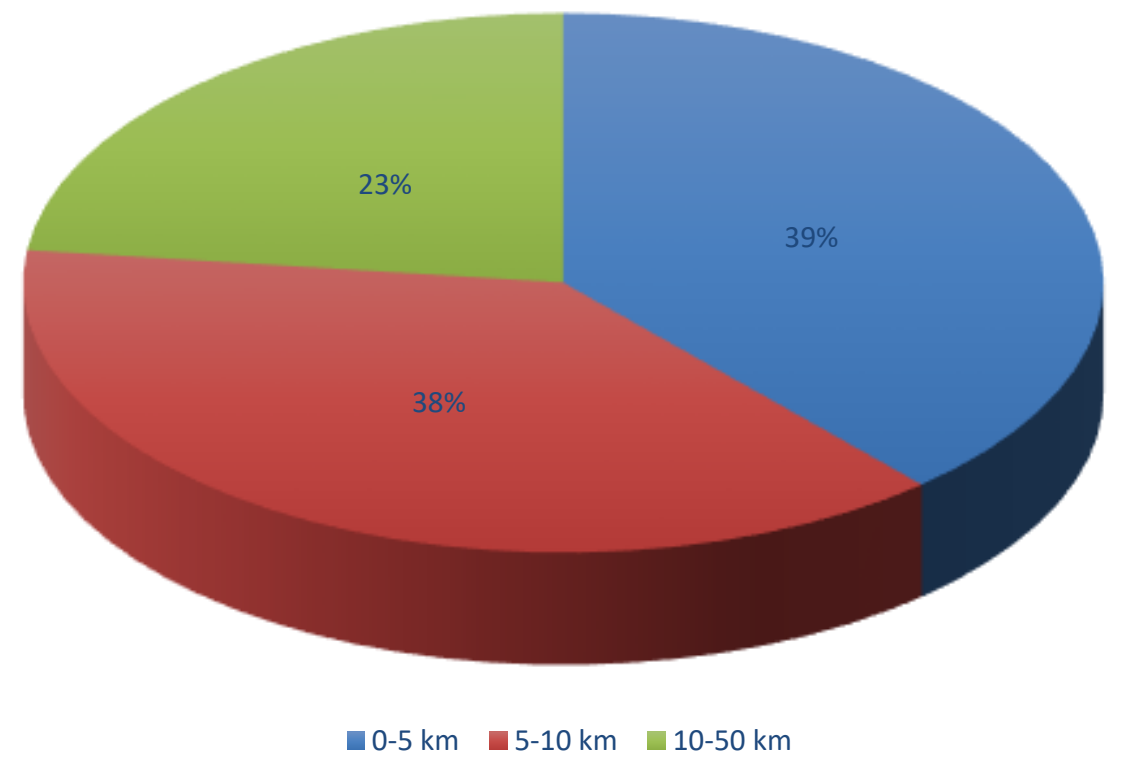

Şekil 8. İncelenen tesislerde yerleşim yerlerine uzaklık dağılımı

\section{İşletmelerin Üretim Miktarları}

Antalya, Isparta ve Afyonkarahisar illerinde yapılan çalışmada 0-500 ton/yıl arası üretim yapan işletme sayısı 3 adet, 500-1000 ton/yıl üretim yapan tesis sayıs1 5 adet, 1000-5000 ton/yıl arası üretim yapan tesis sayıs1 4 adet olarak belirlenmiş olup 5000 ton/yıl üzeri üretim yapan tesis sayısı 1 adet olarak saptanmıştır. 


\section{İșletmelerin İhracat Durumları}

Araştırılan tesisler $\mathrm{AB}$ ülkelerine ve diğer bazı ülkelere ihracat yapmaktadırlar. Bu verilere göre; 0500 ton/y1l aras1 ihracat yapan tesis sayıs1 5, 500-1000 ton/y1 aras1 ihracat yapan tesis sayıs1 4, 10005000 ton/y1l arası ihracat yapan tesis sayıs 2 ve son olarak 5000 ton/y1l aras1 ihracat yapan tesis sayıs1 1'dir (Şekil 9).

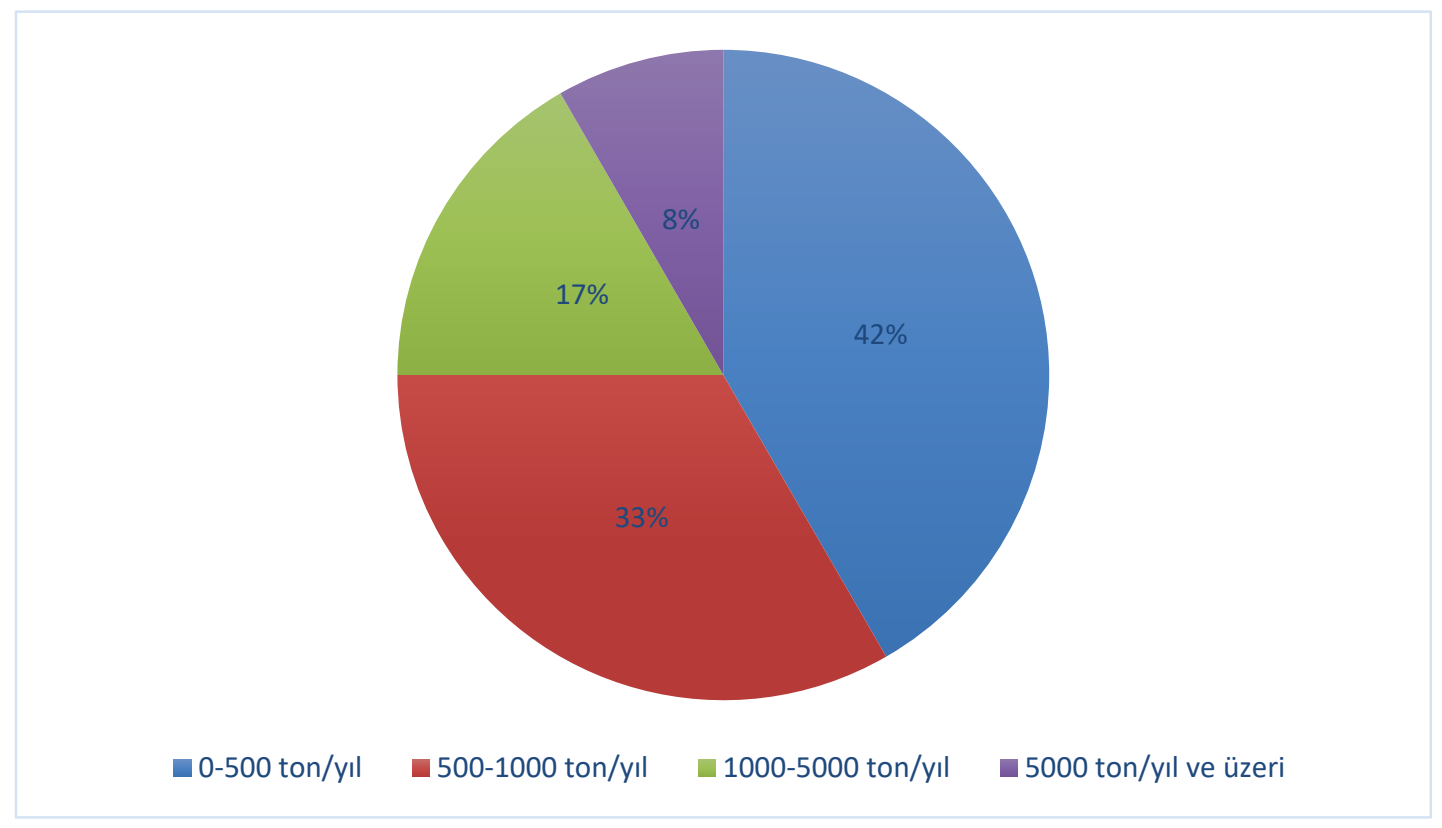

Şekil 9. İncelenen tesislerin yapmış oldukları ihracat dağılımı.

\section{TARTIŞMA ve SONUÇ}

Göller Bölgesi'nde yer alan Isparta, Antalya ve Afyonkarahisar illerinde yapılan bu çalışmada işleme tesisleri birçok yönüyle incelenmiştir. İşletmelerin kuruluş tarihleri incelendiğinde su ürünleri işleme sektörünün ülkemizde çok eskiye dayanmadığı, yeni ve gelişmekte olan bir sektör olduğu görülmüştür. Özellikle son kurulan tesislerin daha profesyonel olarak kurulduğu tespit edilmiştir. Çalışmada ele alınan işletmelerin çoğunun son 15 yılda kurulduğu en eski işletmenin 1981 yılında kurulduğu tespit edilmiştir. Çalışmadaki tesislerden \%8'i 1980-1990 yıllarında, \%15' i 1991-2000 yıllarında, \%31' i 2001-2010 yılları arasında, \%46'sı ise 2011-2019 yılları arasında kurulmuştur (Şekil 1).

Çalışmada Antalya'da 5 (\%38), Isparta'da 4 (\%31), Afyonkarahisar'da 4 (\%31) su ürünleri işleme tesisi bulunduğu tespit edilmiştir (Şekil 2). Tesislerin konumu kurulu kapasitelerini etkilemektedir. Örneğin hem deniz hem iç sulardan elde edilen ürünlerin bol olduğu Antalya'daki işletmelerin toplam kurulu kapasiteleri 19408 ton/yıl iken (\%75), hammadde kaynağı olarak genellikle iç su ürünlerinin ağırlıkta olduğu Isparta ve Afyonkarahisar illerinde bulunan tesislerin toplam kurulu kapasiteleri 6552 ton/yıldır (\%25) (Şekil 3).

Aral (2009), Ege ve Marmara bölgelerinde bulunan 25 tesis üzerinde yapmış olduğu çalışmada tesislerin en eski kuruluş tarihinin 1960'lara dayandığı ancak büyük çoğunluğunun son 10 yılda kurulduğu, hammadde kaynağına yakın bölgelerde bu işletmelerin yoğun olduğu tespit edilmiştir (Aral, 2009). Türkiye'de 1978'lerde başlayan su ürünleri işleme faaliyetleri asıl gelişimini 1990'lı yıllarda göstermiştir. Gerek işletme sayısının artması gerekse de teknik ve hijyenik şartlarda iyileştirmeye bağlı olarak tesis ve ürün kalitesinde bir artış görülmektedir. Başta büyük firmalara ürünlerini satan firmalar daha sonra kendini yenileyip geliştirerek kendi isimleriyle ihracat yapar duruma gelmişlerdir (Çapkın vd., 2008).

Yapılan çalışmada personel durumu ile ilgili elde edilen veriler şöyledir; Avcılık sezonuna göre çalışan, örneğin Afyonkarahisar'da bulunan sadece kerevit işleyen bir tesis, kerevit av sezonu kısa olduğundan daha çok sezonluk işçi çalıştırmaktadır. Antalya'da bulunan başka bir tesis hem avcılık hem yetiştiricilik ürünlerini işlediği için daimi işçiyi daha fazla çalıştırmaktadır. Çalışmamıza konu 
olan işletmelerde; 117 adet sezonluk işçi (\%25), 281 adet daimi işçi (\%60), 23 adet yevmiyeci işçi (\%25), 10 adet tekniker (\%2), 22 adet su ürünleri mühendisi (\%5), 1 adet gida mühendisi ve 12 adet diğer personel (aşçı, şoför, güvenlikçi vb) (\%3) çalışmaktadır (Şekil 4). Sorumlu yöneticiler genellikle su ürünleri mühendislerinden seçilmektedir. Ancak incelenen tesislerin çoğunda yetişmiş ve tecrübeli teknik eleman bulmakta güçlük yaşandığı belirtilmiştir.

Türkiye'de kültür balıkçılığı yapan işletmeler üzerine yapılan bir çalışmada, bu işletmelerin büyük çoğunluğunda iş gücü sorunu olduğunu ve yeterince teknik eleman bulamadıkları bildirilmiştir. Aynı çalışmada diğer hayvansal üretimlere göre su ürünleri yetiştiriciliğinde daha fazla deneyime ve bilgiye sahip olan teknik elemana ihtiyaç duyulduğu belirtilmiştir. İşletmeler genellikle köy, belde gibi sosyal alt yapısı olmayan yerlerde kurulmuştur. $\mathrm{Bu}$ durum nitelikli personelin istihdam edilmesini ve devamlılığını olumsuz yönde etkilemektedir. Nitekim su ürünleri tesisleri çok sık personel değiştirmektedir. Muğla bölgesinde yaklaşık olarak 200 teknik personel (Su ürünleri mühendisi, veteriner, ziraat mühendisi, tekniker vb) ve 2000 civarı işçi çalışmaktadır (Özdemir ve Dirican, 2006).

Aral (2009), Ege ve Marmara bölgelerinde bulunan 25 tesis üzerinde yapmış olduğu çalışmada işletmelerde daha çok daimi işçi çalıştırıldığını vurgulamıştır. İşletmelerin sadece beş adedinde 10-50 arası mevsimlik işçi çalışmakta olup diğer tesislerin daimi işçi çalıştırdığını da belirtmiş̧tir.

Yapmış olduğumuz çalışmada incelenen tesislerde 18-25 yaş grubundan 54, 25-30 yaş grubundan 144, 30-35 yaş grubundan 131, 35-45 yaş gurubundan 92, 45 yaş üstü yaş gurubundan 25 kişi çalıştığ1 tespit edilmiştir. Orta yaş grubu, işleme tesislerinde daha çok tercih edilmektedir. Çalışan personelin 305' i kadın, 141'i erkek personelden oluşmaktadır (Şekil 5, 6). Bu personelin hepsi balık tükettiğini belirtmişlerdir. İncelenen tüm işletmelerdeki personelin hijyen eğitimi ve iş güvenliği eğitimi aldığı tespit edilmiştir.

Beyşehir'de mevcut su ürünleri işleme tesisleri üzerinde yapılan bir çalışmada, en önemli problemin kalifiye personel bulunması olduğu tespit edilmiştir. İşletmelerin tamamında daimi kadrolu mühendis çalıştırıldığı, çalışanların genellikle 16-25 yaşındaki kadınlardan oluştuğu belirlenmiştir (Çapkın vd., 2008).

Güvenli gıda temini sadece biyolojik, kimyasal ve diğer bulaşma yollarından tüketici sağlığını korumak için değil, sağlıklı beslenmek ve sağlıklı yaşam için de gereklidir. Tüketicinin korunması ve gıda ile bulaşan hastalıkların önlenmesi gıda güvenirliği programının temel unsurlarından birisidir. Gıda güvenirliği, gıdanın kaliteli ve sağlıklı oluşu kavramlarını kapsamaktadır. Gıda güvenirliğine ilişkin sistemleri TQM (Total Quality Management), ISO 9000 (Kalite Yönetim Sistemi Standard1), GMP (Good Manufacturing Practices), GHP (Good Hygiene Practises), ve HACCP (Hazard Analysis Critical Control Point)olarak özetleyebiliriz. Aslında bu kavramlar, birbirinden ayrılmaz bir bütündür (Korkut, 2002; Bulduk, 2003).

İncelenen tesislerde HACCP kalite programının tüm işletmelerde uygulandığı görülmüştür. 13 tesisin tamaminda HACCP belgesi bulunmaktadır. 12'sinde IFS, 9 unda BRC, 6 sin da ISO 9001, 4' ünde ISO 22000, 3'ünde GLOBAL GAP, 2' sinde ISO 14001 ve 1'inde OHSAS 18001 uluslararas1 belgeler bulunmaktadır.

$\mathrm{Su}$ ürünleri ile ilgili olarak belli başlı direktifler mevcuttur. Bunların en geniş kapsamlısı olan "Su Ürünlerinin Üretim ve Pazara Sunumu Sonrasındaki Sağlık Koşullarını" belirleyen 91/493/EEC sayılı direktif diğer direktiflerin temelini oluşturmaktadır. Bu kapsamda üretim ve işleme faaliyetleri, kalite, ürün güvenliği ve sunumu ele alınmıştır. Benzer amaçla çıkarılmış olan 91/492/EEC sayılı direktifte canlı çift kabuklu üretilmesi ve pazara sunulması hakkındaki bilgilerle birlikte ilgili yapı malzemeleri, binalar, tanklar ve ürünlerin depolanması hakkında bilgi vermektedir. Bu çerçevede gerekli mikrobiyolojik analizi yapacak laboratuvarın nitelikleri de belirtilmiştir. Diğer taraftan, 94/356/EEC sayılı direktifin temeli, HACCP' e dayanmaktadır. Bir kalite kontrol uygulaması olan HACCP, balığın işlenmesi sırasındaki tehlike yaratabilecek aşamaları belirleyip kritik kontrol noktalarını bu sonuçlarına göre belirleme temeline dayanmaktadır. Burada amaç, işlem sırasında oluşabilecek zararı mümkün olduğu ölçüde çabuk belirleyip ürün zarar görmeden önlem almaktır (Anonim, 2001). Böylesine önemli bir belgenin incelenen tüm işleme tesislerinde bulunduğu belirlenmiştir.

Sağlam (2017), Toplam kalite yönetimi (TKY) uygulamalarından HACCP' i 12 işletmenin, ISO' yu 5 İşletmenin, GMP ve AB ihracat sertifikasının da 2 işletmenin uyguladığını bildirmiştir. Buradan anlaşılacağı üzere HACCP genel olarak işletmelerin çoğunda bulunmakta olup diğer TKY 
uygulamalarının içerisinde \%75'lik oranı kapsamaktadır. Çalışmada İstanbul ilindeki işletmelerin $\% 12,5$ ' inde $\mathrm{AB}$ ihracat sertifikası olduğu bildirilmiştir.

İncelenen su ürünleri işleme tesislerinin en büyük problemlerinden birisi hammadde teminidir. Çalışmamızdaki tesislerin 9' u hammaddeyi hem avcılık hem de yetiştiricilik yoluyla elde etmektedir. Geriye kalan 4 tesis ise sadece yetiştiricilik yoluyla hammadde kaynağı sağlamaktadır. Bu tesislerden hammadde kaynağı olarak 7'si yerli ve yabancı ürünleri kullanırken, 6 tanesi sadece yerli ürünleri tercih etmektedir (Tablo 1). Diğer bölgelerde olduğu gibi incelediğimiz 13 tesisin tamamının ana problemi hammadde teminindeki güçlüklerdir.

Tezcan (2005), Konya'da faaliyet gösteren 8 adet su ürünleri işleme tesisinin yapısal analizini ve verimliliklerinin incelenmesi konulu çalışmasında; Konya'da bulunan su ürünleri işleme tesislerinin gerekli alt yapı, teknik ve fiziksel şartları taşıdıkları, pazarlama sorunu ve hammadde temininde problem yaşadıkları belirtilmiştir.

Isparta, Afyonkarahisar ve Antalya illerinde gerçekleştirilen bu çalışmada tesislerin \%54'ünün tam kapasite ile çalıştığ 1 \% \%'s'sının \%80-90, \%15'inin \%60-70 ve \%15'inin de \% 50 ve altı kapasite ile çalıştı̆̆ saptanmıştır (Şekil 7). İstanbul ilindeki su ürünleri işleme tesislerinin genel yapı ve işleyişi ile ilgili yapılan bir çalışmada tesislerin yıllık kurulu kapasitelerinin 28ton ile 12000 ton/yıl arasında değiştiği, kapasitelerinin \%98'i oranında faaliyet gösterdikleri belirlenmiştir (Sağlam, 2017). Isparta Antalya ve Afyonkarahisar'da yaptığımız bu çalışmada tesislerin \%54'ünün tam kapasite ile çalıştığı belirlenmiş, bu yönüyle farklı bir durum ortaya çıkmıştır. İstanbul gerek hammaddeye yakınlık gerekse iş gücü vb. nedenlerle maliyet olarak daha avantajlı olduğu için kapasite kullanım oranı daha yüksektir.

İşleme yöntemleri incelendiğinde 13 tesisin taze, soğutulmuş ya da dondurulmuş olarak ürünlerini işlemekte olduğu, Afyonkarahisar'da bulunan bir tesisin sıcak dumanlanmış alabalık ürettiği belirlenmiştir. Antalya' da bulunan tesislerin konserve hariç tüm işleme yöntemlerini kullanarak üretim yaptığı görülmüsştür (Tablo 2). Sağlam (2017), İstanbul'da işleme tesisleri üzerine yaptığ1 çalışmasında tesislerin taze soğutulmuş - dondurulmuş-tütsülenmiş-kurutulmuş - tuzlanmış - konserve ve surimi gibi çok farklılık gösteren bir ürün yelpazesi ile çalıştıklarını tespit etmiştir.

Her üç ilde bulunan su ürünleri işleme tesislerinin yerleşim yerine olan uzaklığı araştırılmış ve tesislerin \%38'inin 5-10km, \%39'unun $0-5 \mathrm{~km}$ ve $\% 23$ 'ünün $10-50 \mathrm{~km}$ uzakl1kta olduğu belirlenmiştir (Şekil 8). İncelenen işleme tesislerinin üretim miktarları illere ve firmalara göre değişmektedir. \%38'i $500-1000$ ton/y1l, \%31'i 1000-5000 ton/y1l, \%23'ü 0-500 ton/y1l ve \%8'i 5000 ton/y1lın üzerinde üretim yapmaktadır. İhracat verilerine göre tesislerin \%42'si 0-500 ton/y1l, \%33'ü 500-1000 ton/y1l, \%17'si 1000-5000 ton/y1l ve \%8'i 5000 ton/y1lın üzerinde satış gerçekleştirmektedir (Şekil 9).

Her 3 ildeki su ürünleri işleme tesislerindeki personelin çoğunun ilkokul mezunu olduğu ancak hemen hemen hepsinin iş güvenliği ve hijyen eğitimi aldığ 1 belirlenmiştir. Aral (2009), su ürünleri işleme tesislerinin hijyen durumlarını belirlemeye yönelik yaptığı araştırmasında incelediği tesislerdeki çalışanların eğitim durumlarına ile ilgili küçük yerleşim yerlerindeki tesislerde çalışanların ilkokul düzeyinde, tesisin büyük şehirde olması veya şehre yakın olması durumunda eğitim seviyesinin ortaokul seviyesine yükseldiğini belirlemiştir. Eğitim seviyesinin düşük olması kaliteyi etkileyen bir unsurdur.

Çalışmamızdaki işleme tesislerin karşılaşmış olduğu birçok problem mevcuttur. Bunlardan en önemlisi hammadde sorunudur. Avcılığı yapılan türlerin sürdürülebilirliğinin sağlanamaması, yetiştiricilik tesislerinin yeterince üretim yapamaması, yetiştiricilik tesislerinin girdilerinin yüksek olması hammadde konusunda problemler ortaya çıkarmaktadır. Mol ve Ulusoy (2010), Türkiye su ürünleri işleme sektörünün sorunlarına ilişkin yaptıkları çalışmada hammadde sorunu nedeniyle tam kapasite ile çalışamadıklarını bildirmişlerdir. Diğer bir çalışmada tesislerin en büyük sıkıntısının, hammadde sürekliliğinin olamaması şeklinde yorumlanmıştır (Emir vd., 2012). Yaptığımız bu çalışmada da aynı sorunun hala devam ettiği görülmüştür.

Artan maliyetler, kalifiye eleman bulmaktaki zorluklar ve devlet kurumlarındaki prosedürlerin yavaş işlemesi gibi problemler de üretimi olumsuz yönde etkilemektedir. Bazı işletmelerin dile getirmiş olduğu kontrolsüz işletmelerin rekabeti olumsuz etkilediği iddia edilmiş ve kamu kurumları tarafından yeterince denetlenmediği vurgulanmıştır.

Dünyada olduğu gibi ülkemizde en hızlı gelişen sektörlerden birisi su ürünleri sektörüdür. İnceleme yaptığımız illerde tespit ettiğimiz kadarıyla av baskısı, su ürünleri yetiştiriciliğindeki girdilerin 
artması, yetiştiriciliği yapılan türlerin üretimindeki güçlükleri ortaya çıkarmaktadır. Dolaylı olarak bu da su ürünleri işleme tesislerinin hammadde kaynăg 1 temininde güçlüklere sebep olmaktadır. Son zamanlarda ihracatın artması hammaddeye olan talebin artmasına; bu durumun, hammadde maliyetinin yükselmesine neden olduğu belirtilebilir.

Yapılan bu çalışmada tüm personel hijyen eğitimi ve iş güvenliği eğitimi almıştır. Söz konusu işleme tesislerinde, yetişmiş personel bulmaktaki güçlükler, çalışanların hijyen ve iş güvenliği eğitimi alsalar dahi bilgi yetersizliğinden dolayı üretimde problemler ortaya çıkarttı̆̆ belirtilmiştir. Özellikle yetişmiş sorumlu su ürünleri mühendislerinin ve teknik elemanların tecrübe kazandıktan sonra iş değiştirmesi işleme tesislerini zor durumda bırakan bir durum olarak karşımıza çıkmıştır.

Çalışmada incelenen tesis yöneticilerinin özellikle öne çıkartmak ve çözüm istedikleri konular arasında kamu kurumlarındaki işleyişin hızlandırılması, işletmelerin sık denetlenmesi, söz konusu şartları sağlamayanların üretim yapmasına izin verilmemesidir. Avcılık yoluyla elde edilen ekonomik türlerin balık unu, yağı ve balık yemi yapımında kullanımının önüne geçilmesi, ekonomik değeri olmayan balıkların (çaça gibi) bu amaçlarla kullanılması işleme sektöründe hammadde ihtiyacına kısmen çözüm bulacağı açıktır. Avcılığı yapılan türlerin devlet yaptırımlarıyla korumaya alınması, yasa dışı avcılığın denetlenmesi önem arzetmektedir.

2010 yılında yapılan bir çalışmada ülkemizdeki su ürünleri işleme tesislerinin karşıllaştı̆̆ 1 sorunlardan birisinin pazarlama olduğu belirtilirken (Köse vd., 2010) yaptığımız bu çalışmada İncelenen tesislerin pazar bulma konusunda problemler yaşamadığ 1 görülmüştür. Bulundukları illerde istihdam sağladıkları, yaptıkları ihracat nedeniyle balık üreticisinden avcısına kadar ekonomik döngüye katkı yaptıkları saptanmıştır. Bu tesislerin yılda yaklaşık olarak 25000 ton ihracat yaptığı düşünülürse ülke ekonomisine önemli katkılarının olduğu düşünülmektedir. Yapılan çalışmada Göller Bölgesi’nde faaliyet gösteren bu işletmelerin gerek pazar durumu ve bölge ekonomisine sağladıkları katkı, üretim durumları, sağladıkları istihdam kısacası olanakları ile bölge ekonomisinde söz sahibi işletmeler olduğu görülmüştür. Türkiye'nin su ürünleri potansiyeli, son yıllarda su ürünleri alanında meydana gelen gelişmeler sektörün gelecekte daha da umut verici bir sektör olduğunu göstermektedir. $\mathrm{Bu}$ alanda yapılacak yeni yatırımlarla su ürünleri hem işleme hem yetiştiricilik anlamında daha da ileriye gidecektir. Sektörün bu denli gelişmesinde elbette ki su ürünleri mühendislerinin rolü büyüktür. Ümidimiz daha iyi bir istihdam daha iyi çalışma koşulları, daha yüksek oranda dünya standartlarında üretim yapmak ve ülke ekonomisine katkı sağlamaktır.

Teşekkür: Bu çalışma, yüksek lisans tezinden özetlenmiştir.

\section{KAYNAKLAR}

Anonim. (2001). Sekizinci Beş Yıllık Kalkınma Planı Su Ürünleri ve Su Ürünleri Sanayi Özel İhtisas Komisyonu Raporu Ankara 2001. DPT-2575 OIK:588 ISBN 975. 19. 2714-5, 101-102.

Anonim. (2014). Su Ürünleri yetiştiriciliği sektör raporu. Su ürünleri Yetiştiricileri Üretici Merkez Birliği, Ankara, 71.

Aral, N. (2009) Su Ürünleri İsleme Tesislerinde Hijyen Uygulamaları. Muğla Üniversitesi Fen Bilimleri Enstitüsü, Yüksek Lisans Tezi, 138 Muğla

Bulduk, S. (2003).Gida ve Personel Hijyeni, Ankara. ISBN-975-8326-71-6.179s.

Çapkın, K., Korkut, S., Şevik, R., \& Olgun, M. (2008). Determination structures and problems, on processing enterprises of fishery in Beyşehir region. (In Turkish). Journal of fisheriessciences.com, 466-474.

Dağtekin, M., \& Ak, O. (2007). Doğu Karadeniz Bölgesinde Su Ürünleri Tüketimi, İhracat ve İthalat Potansiyeli. Yunus Araştırma Bülteni, 7 (3), 14- 17.

Emir, M., Karadağ, H.O., Ege, F., \& Ceyhan,V. (2012). 10.Ulusal Tarım ve Ekonomi Kongresi, 5-7 Eylül 2012, Konya, ss 828-838.

Korkut, H. (2002). Gıda Güvenliği ve HACCP. Glda Teknolojisi Dergisi, 6 (8), 24-27.

Kömürlü, U., \& Atar, H.H. (2019). Su Ürünlerinde Kredi Uygulamaları, Üçüncü Sektör Sosyal Ekonomi Dergisi, $54(3), 1300-1318$

Köse, S. Gökoğlu, N., Mol Tokay, S., Baygar, T., Özer, N.P., Çolakoğlu, F.A., \& Alçiçek, Z. (2010). Türkiye' deki Su Ürünleri Işsleme Sektörünün Durumu, Sorunlart ve Çözüm Önerileri. Türkiye Ziraat Mühendisliği VII. Teknik Kongresi. 11-15/01/2010, Ankara, ss.821-852.

Mol,S., \& Ulusoy, Ş. (2010). Türkiye su ürünleri işleme sektörünün sorunları ve çözüm önerileri. Journal of FisheriesSciences.com 4(2), 152-158 (2010). 10.3153/jfscom.2010015. 
Özdemir, N., \& Dirican, S. (2006). Muğla İlinde Kültür Balıç̧ılığı ve Sorunları. Ege Üniversitesi Su Ürünleri Dergisi, 23 (1/2), 283-286.

Sağlam, F.T. (2017). İstanbul İli su ürünleri işleme tesislerinin genel yapısı ve işleyişi. Namık Kemal Üniversitesi Fen Bilimleri Enstitüsü Tarım Ekonomisi Anabilim Dalı Yüksek Lisans Tezi Tekirdağ, 119s.

Tezcan, M. (2005). Konya'daki Su Ürünleri İşleme Tesislerinin Yapısal Analizi Ve Verimliliklerinin Değerlendirilmesi. Selçuk Üniversitesi Fen Bilimleri Enstitüsü Zootekni Anabilim Dalı Yüksek Lisans Tezi. 32s.

Ünlüsayın, M., Bilgin, Ş., Günlü, A., \& İzci, L. (2005). Türkiye'nin Avrupa Birliği (AB)'ne Katılım Sürecinde $\mathrm{Su}$ Ürünleri İşleme Tesislerimizin Mevcut Durumuna Bir Bakış. TSE Standard Ekonomik ve Teknik Dergi, Y/44, N/528, Aral1k, 55-59.

www.tuik.gov.tr/PreTablo.do?alt_id=1005

www.tarimorman.gov.tr/sgb/Belgeler/SagMenuVeriler/BSGM.pdf

www.ggbs.tarim.gov.tr 